

\section{DISCLAIMER}

This report was prepared as an account of work sponsored by an agency of the United States Government. Neither the United States Government nor any agency Thereof, nor any of their employees, makes any warranty, express or implied, or assumes any legal liability or responsibility for the accuracy, completeness, or usefulness of any information, apparatus, product, or process disclosed, or represents that its use would not infringe privately owned rights. Reference herein to any specific commercial product, process, or service by trade name, trademark, manufacturer, or otherwise does not necessarily constitute or imply its endorsement, recommendation, or favoring by the United States Government or any agency thereof. The views and opinions of authors expressed herein do not necessarily state or reflect those of the United States Government or any agency thereof. 


\section{DISCLAIMER}

Portions of this document may be illegible in electronic image products. Images are produced from the best available original document. 


\title{
Gamma-Ray Isotopic Ratio Measurements for the Plutonium Inventory Verification Program
}

\author{
John F. Lemming, Francis $X$. Haas and Jack $Y$. Jarvis
}

Issued: August 25, 1976

\section{NOTICE}

This report was propared as an account of work sponsored by the United States Government. Nelther the United States nor the United Stotes Eneroy Aesearch and Dovelopment Administration, nor any of their employees, nor any of their. contractors, subcontractors, or thelr emplovees, makes any warranty, express or implied, or assumes any legal liablitty or responsibllity for the accuracy, com-

ploteness or ueefulnose of any information, apporatus, product or process disclosed. or represente that its use would not infringe privately owned rights.

PAINTED IN THE UNITED STATES OF AMERICA

Avallable from

Netlonal Technical Information Service

U. S. Department of Commerce

6286 Port Royal Road

Suilinuflald, Virainia 22161

Price: Printed Copy $\$ 3.50 ;$ Microfiche $\$ 2.25$

\section{MONSANTO RESEARCH CORPORATION}

A Subsidiary of Monsanto Company

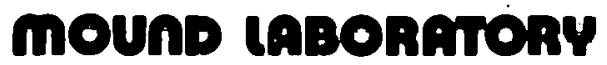

Miamisburg, Ohio

45342

operated for

\section{UNITED STATES ENERGY RESEARCH AND. DEVELOPMENT ADMINISTRATION}

U. S. Government Contract No. E-33-1-GEN-53 
ABSTRACT . . . . . . . . . . . . . . . . . . . . . . . . . . . . . . 3

INTRODUCTION . . . . . . . . . . . . . . . . . . . . . . . . . . . . . . . . . . 4

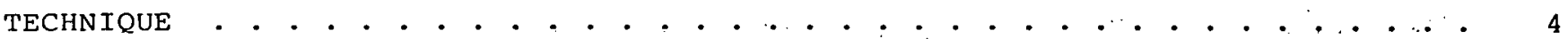

DATA ACQUISITION . . . . . . . . . . . . . . . . . . . . . . . . . . . . 5

DATA ANALYSIS • . . . . . . . . . . . . . . . . . . . . . . . . . . . . . 5

RESULTS

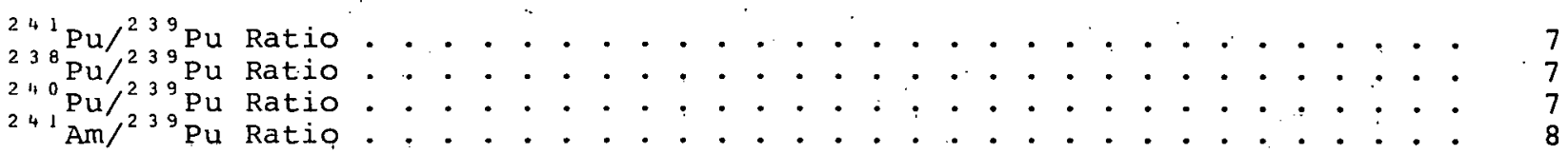

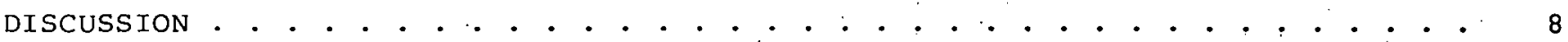

REFERENCES . . . . . . . . . . . . . . . . . . . . . . . . . . . . . 10

DISTRIBUTION 
The Plutonium Inventory Verification Program at Mound Laboratory provides a nondestructive means of assaying bulk plutonium-bearing material. The assay is performed by combining the calorimetrically determined heat output of the sample and the relative abundances of the heat-producing isotopes. This report describes the method used for the nondestructive determination of plutonium-238, $-240,-241$ and americium-24l relative to plutonium-239 using gamma-ray spectroscopy for 938 plutonium-239 material. Comparison of chemical data on aliquots of samples to the nondestructive data shows accuracies of \pm 78 for ${ }^{23}{ }^{9} \mathrm{Pu} /{ }^{2}{ }^{9} \mathrm{Pu}, \pm 158$ for ${ }^{240} \mathrm{Pu} /{ }^{23}{ }^{3} \mathrm{Pu}$, \pm 38 for ${ }^{241} \mathrm{Pu} /{ }^{239} \mathrm{Pu}$, and \pm 78 for ${ }^{241} \mathrm{Am} /{ }^{239} \mathrm{Pu}$. 
The Plutonium Inventory Verification Program $^{1-4}$, was established at Mound Laboratory to give an independent nondestructive verification of assay measurements at contractor facilities.

As a part of this program, auditors select samples from contractor inventories and send them to Mound Laboratory for calorimetric assay. ${ }^{5}$ The variety of categories which have been assayed are oxide, metal, incinerator ash, ash heel, plutonium-238 scrap, fluoride, crucibles, slag, scarfings, and green cake.

The scrap samples are normally packaged in gallon cans containing 20 to $400 \mathrm{~g}$ of plutonium. The remaining samples are packaged in quart cans containing 10. to $2500 \mathrm{~g}$ of plutonium.

This report describes the gamma-ray spectroscopic techniques used to nondestructively determine the isotopic ratios necessary for calorimetric assay. Time limitations on the inventory require three samples to be processed per day, limiting gamma-ray data acquisition times to approximately $4 \mathrm{hr}$. The data contained in this report were obtained in the time phase ending December 31 , 1975 .

TECHNIQUE

The bases for the nondestructive measurement of plutonium isotopic ratios using passive high-resolution gamma-ray spectrometers have been.discussed and reviewed by several authors. ${ }^{-15}$ In general, a spectral group whose members belong to different isotopes is analyzed. Ratios of the areas of gamma-ray peaks are related to the isotopic abundance ratios by the expression:

$$
\frac{I_{i}}{I_{j}}=\frac{N_{i} \lambda_{i} B_{i}}{N_{j} \lambda_{j} B_{j}} \frac{\varepsilon_{i}}{\varepsilon_{j}} S_{j}
$$

where $I, N, \lambda, B, \varepsilon$ and $S$ are the measured peak area, the number of nuclei, the nuclear decay constant, the absolute branching intensity, the detector efficiency, and the self-absorption for the gammarays with energies $E_{i}$ and $E_{j}$ from isotopes $i$ and $i$, respectively.

The relative efficiency, which is a product of the detector efficiency and the absorption coefficient, varies with energy. Although the efficiency curve can be measured, the absorption effects from an unknown package are often impossible to predict. For this reason, gamma-ray peak pairs whose energies differ by less than $10 \mathrm{keV}$ are chosen, and the assumption is made that the ratio of the relative efficiencies is 1 .

From a study of the published decay data on the plutonium isotopes and americium241 , several sets of peak pairs were chosen for calculating isotopic ratios. Table 1 is a summary of these gamma-ray energies, the branching ratios, and the half-lives necessary for the calculations. The nuclear decay constants have been taken from Gunnink and Morrow. ${ }^{16}$

Table 1

LIST OF GAMMA-RAYS AND BRANCHING INTENSITIES OF ISOTOPES OF INTEREST

\begin{tabular}{|c|c|c|c|}
\hline Isotope & $\begin{array}{l}\mathrm{T}_{\frac{1}{2}} \\
\text { (days) }\end{array}$ & $\begin{array}{l}\text { Energy } \\
\text { (kev) }\end{array}$ & $\begin{array}{l}\text { Branching } \\
\text { Intensity }\end{array}$ \\
\hline $2^{38} \mathrm{Pu}$ & $3.2 \times 10^{4}$ & 152.77 & $1.01 \times 10^{-5}$ \\
\hline $2{ }^{39} \mathrm{Pu}$ & $8.908 \times 10^{6}$ & $\begin{array}{l}141.64 \\
144.19 \\
146.05 \\
203.52 \\
637.97 \\
640.15 \\
658.99\end{array}$ & $\begin{array}{l}3.11 \times 10^{-7} \\
2.84 \times 10^{-6} \\
1.13 \times 10^{-6} \\
5.63 \times 10^{-6} \\
2.50 \times 10^{-8} \\
7.95 \times 10^{-8} \\
9.50 \times 10^{-8}\end{array}$ \\
\hline $240 \mathrm{Pu}$ & $2.41 \times 10^{6}$ & 642.30 & $1.45 \times 10^{-7}$ \\
\hline${ }^{241} \mathrm{Pu}$ & $2.070 \times 10^{8^{a}}$ & 148.60 & $7.74 \times 10^{-2}$ \\
\hline $237 \mathrm{U}$ & 6.75 & 207.97. & $2.080 \times 10^{-1}$ \\
\hline $241 \mathrm{Am}$ & $1.582 \times 10^{5}$ & $\begin{array}{l}146.55 \\
207.98 \\
662.37\end{array}$ & $\begin{array}{l}4.58 \times 10^{-6} \\
7.60 \times 10^{-6} \\
3.46 \times 10^{-6}\end{array}$ \\
\hline
\end{tabular}

Alpha half-life. 
The accuracy and reproducibility of the isotopic ratios determined by gamma-ray spectroscopy depend on the reliability of the extracted gamma-ray peak areas. The primary contribution to the uncertainties associated with each peak area is a function of the resolution of the gammaray spectrometer. Hence, it is recommended that an optimum choice be made of the detector and the electronics to be used (e.g., see Regulatory Guide 5.9):17

The detector system used for our program is a 70-cc Ge(Li) crystal with a resolution of $1.80 \mathrm{keV}$ for the $1332-\mathrm{keV}$ cobalt60 gamma-ray. The gain on the linear amplifier is adjusted so that the energy calibration is $0.26 \mathrm{keV} / \mathrm{channel}$. A 4096channel analyzer is used to acquire the data. A $0.030-i n$. $(0.076-\mathrm{cm})$ cadmium absorber is used to suppress low-energy gamma-rays. The sample-to-detector distance is chosen to give a count rate between 2500 and 4000 counts/sec. Samples are counted for approximately $4 \mathrm{hr}$. The isotopic composition of the plutonium material is assumed to be homogeneous. However, the sample is rotated during counting to average inhomogeneities due to distribution of the plutonium in the sample. Figure 1 shows a spectrum of an oxide sample acquired using the inventory spectrometer described. The peaks which are used in determining the isotopic ratios are labeled.

In addition to the bulk samples, aliquots (1-5 g of material depending on the category) are chosen from selected samples before shipping to Mound Laboratory. These aliquots are assayed using gamma-ray spectroscopy and then dissolved for analysis by radiocounting and mass spectroscopy to aid in the construction of the isotopics and to establish further reliability upon the gamma-ray techniques. The aliquots are packaged in 5-dram glass vials inside aluminum secondary calorimeter cans $(1-1 / 8$ in. $[2.86 \mathrm{~cm}] \times 2-9 / 16$ in. $[6.51 \mathrm{~cm}])$. Because of their lower count rates the aliquots are counted for $8 \mathrm{hr}$.

\section{DATA ANALYSIS}

The spectra are analyzed on an IBM-360/50 computer using the program GAUSS $V .{ }^{3}$

This program uses a nonlinear least-squares. fitting technique to describe the data as Gaussian-shaped peaks on a linear background. The program can be used to extract peak areas for a maximum of five overlapping gamma-ray peaks.

The gamma-ray peak areas are converted to isotopic ratios by the computer program ISOTOP. The branching ratios of Gunnink and Morrow ${ }^{16}$ are used since they give the best agreement with chemical analysis. Table 2 summarizes the conversion factors.

In order to verify the operation of the gama-ray spectrometer, a National Bureau of Standards reference source (NBS-948) whose plutonium characteristics are similar to those of the samples to be inventoried is measured before and after each set of samples.

Table 2

GAMMA-RAYS AND CONVERSION FACTORS USED FOR ISOTOPIC DETERMINATIONS

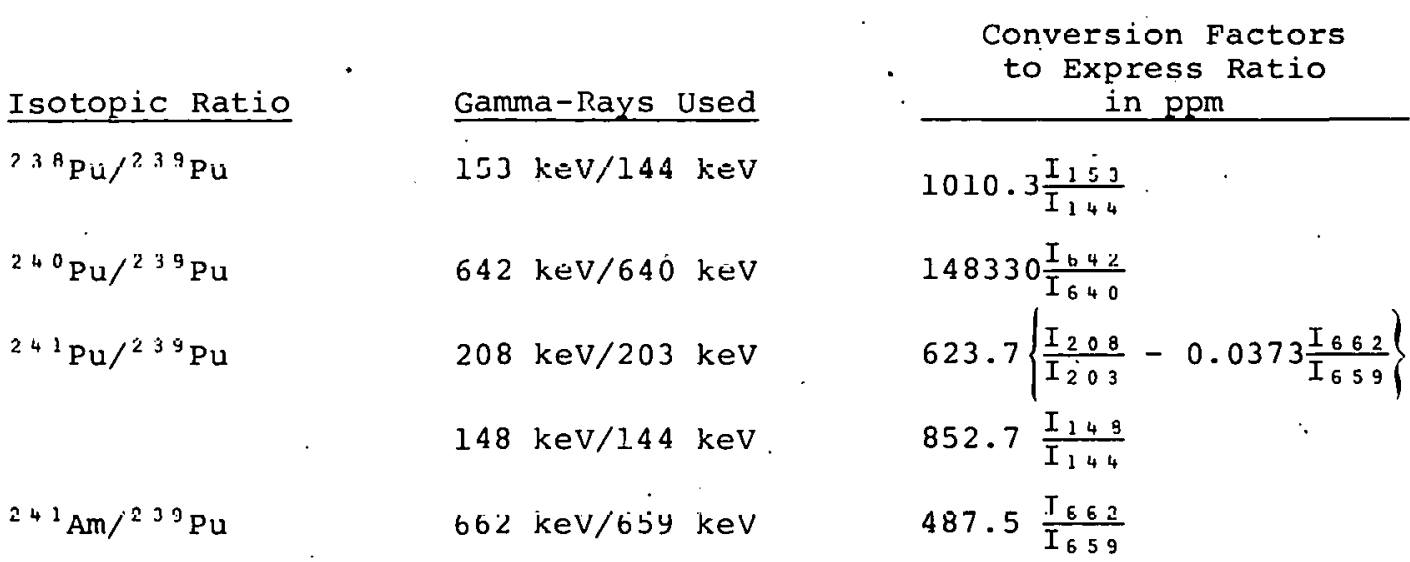




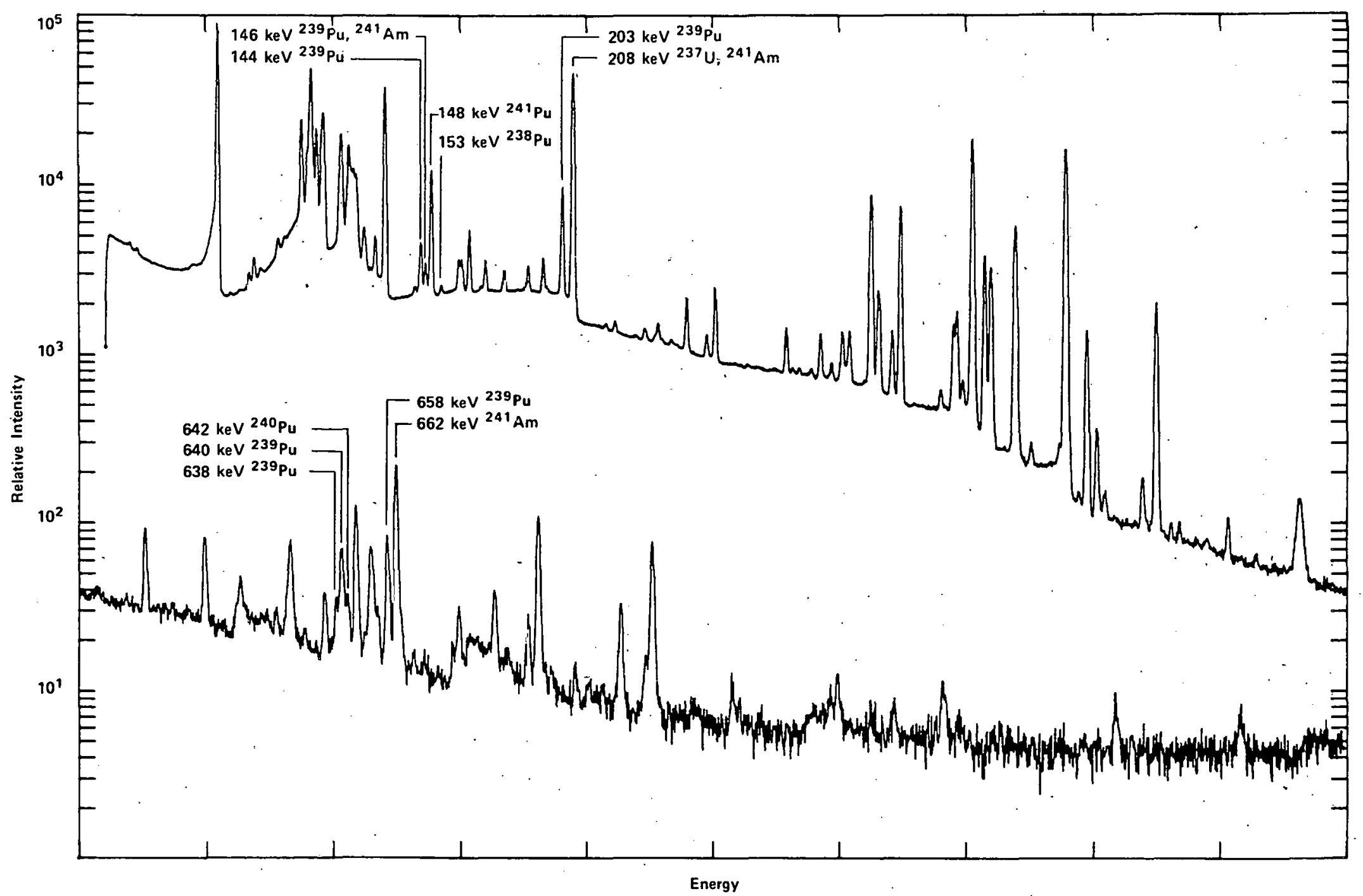

FIGURE 1 - Spectrum of a $292-g$ oxide sample from the plutonium Inventory Verification program obtained with 70-CC Ge(Li) detector No. 813 . 
Because each set of peak pairs used for the isotopic ratio determinations has its own advantages and disadvantages, the ratios will be discussed individually. It should also be reemphasized that the spectra are acquired for approximately $4 \mathrm{hr}$ and that all isotopic ratios are determined from the same set of data. If only one isotopic ratio were necessary or if a multidetector system were used, the experiments could be tailored to improve the accuracies of the individual measurements.

In the following discussions, the isotopic ratios determined by the gamma-ray technique on the aliquots are compared to those determined by radiocounting and/or mass spectroscopy where appropriate. The isotopic ratios measured on the bulk samples are compared to those measured from the aliquot. All of these samples contain approximately $93 \%$ plutonium-239.

\section{$241 \mathrm{Pu} / 2{ }^{29} \mathrm{Pu}$ Ratio}

The ${ }^{24} \mathrm{Pu} /{ }^{2}{ }^{39} \mathrm{Pu}$ ratio is measured using two sets of peak pairs. The 203.5-keV gamma-ray from plutonium-239 and the

208.0-keV gamma-ray from the uranium-237 daughter of plutonium-241 are a convenient pair when uranium-237 is in equilibrium with the parent plutonium-24l. The advantage of this peak pair is that it can be used over a wide range of isotopic fractions. The disadvantage is that a correction must be made for the americium241 contribution to the $208-\mathrm{keV}$ peak. The other set of peaks which is suitable for most of the inventory material is the $148.6-\mathrm{keV}$ gamma-ray of plutonium-24l and the $144.2-\mathrm{keV}$ gamma-ray of plutonium-239. This peak pair cannot be used for reactorgrade plutonium since the area of the 144.2-keV gamma-ray peak cannot be determined with sufficient precision due to its low branching intensity and uranium interferences. Table 3 is a summary of the résults from, four Plutonium Inventory series. In this table, the value obtained from the $140-\mathrm{keV}$ region is compared to that obtained from the $200-\mathrm{keV}$ region. The weighted average from these two values is used for the comparison to mass spectroscopy data and for the comparison of the bulk samples to their aliquots.

Precision runs to check the reproducibility on selected samples have a relative standard deviation of \pm 1.18 . In order to be conservative the uncertainty used for the inventory program is $\pm 3 \%$.

\section{$238^{8} \mathrm{Pu} /{ }^{2}{ }^{9} \mathrm{Pu}$ Ratio}

The 152.8-keV gamma-ray of plutonium-238 is used.with the $144.2-\mathrm{keV}$ gamma-ray of plutonium-239 in those cases where the ${ }^{2}{ }^{1} \mathrm{Pu} /{ }^{2}{ }^{39} \mathrm{Pu}$ ratio determined by the $148.6-$ $\mathrm{keV} / 144.2-\mathrm{keV}$ peak pair agrees with that determined by the 208.0-keV/203.5-keV peak pair. If the $144.2-k e V$ gamma-ray cannot be used, the ${ }^{238} \mathrm{Pu} / 2{ }^{4} 1 \mathrm{Pu}$ ratio is calculated using the $152.8-\mathrm{keV}$ gamma-ray of plutonium-238. and the $148.6-\mathrm{keV}$ gamma ray from plutonium-241. The conversion to the ${ }^{23}{ }^{8} \mathrm{Pu} /{ }^{239} \mathrm{Pu}$ ratio is made by using the ${ }^{241} \mathrm{Pu} /{ }^{239} \mathrm{Pu}$ ratio determined from the 208.0-keV/203.5-keV peak pair.

Table 4 is a comparison of the radiocounting ratio to that obtained by gammaray.techniques for aliquot samples. Except for the spring 175 series, the agreement with the radiocounting data is within the $\pm 6.5 \%$ expected from this peak pair. ig For the spring series, some ambiguities exist in the choice of background for the $152.8-\mathrm{keV}$ peak in the running of GAUSS $v$. Up to $1.5 \%$ differences in peak area were noted for equally valid input parameters. This problem exists for only a few samples. When the 153-kev peak was investigated with a 1-cC LEPS detector (resolution of $600 \mathrm{eV}$ for the 122keV peak of cobalt-57), two peaks were

Table 3 COMPARISON OF ${ }^{241} \mathrm{Pu} / 23{ }^{39} \mathrm{Pu}$ RATIOS

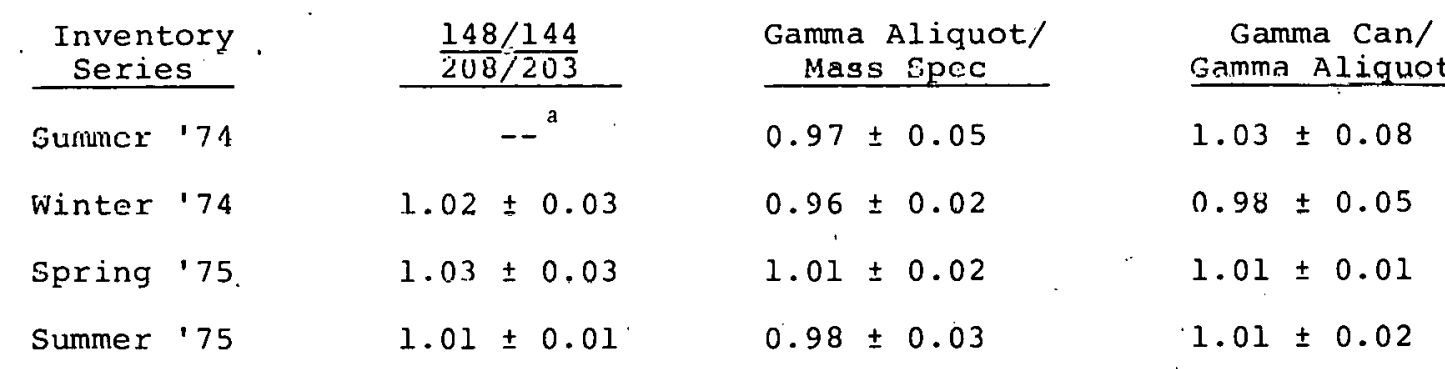

a For the summer 174 series only the $208-\mathrm{keV} / 203-\mathrm{keV}$ peak pair was used. 
resolved in this region. The origin of the background peak remains unsolved. Americium-241 has been ruled out since the concentrations vary from 200 to 370.0 ppm. In all cases when using gamma-ray spectroscopy for isotopic determinations, care must be taken that background gammarays which contribute to the regions of interest do not go undetected.

For bulk samples the background problems in the $152.8-\mathrm{keV}$ region are more pronounced and the uncertainties are generally near $15 \%$.

Table 4

COMPARISON OF ${ }^{238} \mathrm{Pu} /{ }^{239} \mathrm{Pu}$ RATIOS

\begin{tabular}{|c|c|c|c|}
\hline \multicolumn{2}{|c|}{$\begin{array}{c}\text { Inventory } \\
\text { Series }\end{array}$} & $\begin{array}{c}\text { Gamma } \\
\text { Aliquot/ } \\
\text { Radiocounting } \\
\end{array}$ & $\begin{array}{c}\text { Gamma } \\
\text { Can/Gamma } \\
\text { Aliquot } \\
\end{array}$ \\
\hline ummer & 174 & $0.93 \pm 0.06$ & $1.04 \pm 0.20$ \\
\hline Winter & $: 74$ & $1.00 \pm 0.05$ & $1.07 \pm 0.16$ \\
\hline pring & 75 & $1.11 \pm 0.14$ & $1.43 \pm 0.27$ \\
\hline iummer & 75 & $0.99 \pm 0.07$ & $1.00 \pm 0.14$ \\
\hline
\end{tabular}

$2{ }^{40} \mathrm{Pu} / 239 \mathrm{Pu}$ Ratio

This ratio is the most difficult one to determine. The method used employs the 642.3-keV gamma-ray from plutonium-240 and the $646.0-\mathrm{keV}$ gamma-ray from plutonium-239. There are several americium-24l gamma-ray peaks in this area which complicate the spectrum analysia. This pair of gamma-rays has very low intensities and the approximately 4-hr counting times are not long enough to measure the ratio to closer than 15\%. Table 5 shows the comparison of the mass spectroscopic value to that determined by gamma-ray spectroscopy. With better statistics, this peak pair can be used to give the ${ }^{240} \mathrm{Pu} /{ }^{239} \mathrm{Pu}$ ratio to $18.19,20$
Table 5

\begin{tabular}{|c|c|c|c|}
\hline \multicolumn{2}{|c|}{ COMPARISON } & OF $240 \mathrm{Pu} / 239 \mathrm{Pu}$ & ${ }^{9} \mathrm{Pu}$ RATIOS \\
\hline $\begin{array}{r}\text { Invent } \\
\text { Seri } \\
\end{array}$ & ry & $\begin{array}{l}\text { Gamma } \\
\text { Aliquot/ } \\
\text { Mass Spec }\end{array}$ & $\begin{array}{c}\text { Gamma } \\
\text { Can/Gamma } \\
\text { Aliquot }\end{array}$ \\
\hline Summer & 74 & $0.88 \pm 0.14$ & $1.05 \pm 0.15$ \\
\hline Winter & 74 & $0.90 \pm 0.06$ & $0.92 \pm 0.09$ \\
\hline Spring & 75 & $0.94 \pm 0.11$ & $1.03 \pm 0.11$ \\
\hline Summer & 175 & $0.93 \pm 0.11$ & $1.01 \pm 0.18$ \\
\hline
\end{tabular}

$2{ }^{41} \mathrm{Am} / 239 \mathrm{Pu}$ Ratio

The $662-\mathrm{keV} / 659-\mathrm{keV}$ peak pair is used to obtain the ${ }^{241} \mathrm{Am} /{ }^{239} \mathrm{Pu}$ ratio. This region assumes that there is no cesium-137 in the source. Table 6 shows a comparison of bulk sample ratios to those determined from their aliquots. The uncertainty assigned to this ratio for the inventory program is $\pm 7 \%$. Precision runs to check the reproducibility yield $\pm 3.3 \%$.

Table 6

$\begin{array}{cc}\text { COMPARISON OF }{ }^{241} \mathrm{Am} /{ }^{239} \mathrm{Pu} \text { RATIOS } \\ \begin{array}{c}\text { Inventory } \\ \text { Series }\end{array} & \begin{array}{c}\text { Gamma } \\ \text { Aliquot }\end{array} \\ \text { Summer }: 74 & 1.03 \pm 0.18 \\ \text { Wilter }: 74 & 0.95 \pm 0.13 \\ \text { Spring } 175 & 1.01 \pm 0.07 \\ \text { Summer } 175 & 1.01 \pm 0.07\end{array}$

\section{DISCUSSION}

The results of the Plutonium Inventory Verification Program, to date, have demonstrated the usefulness of nondestructive gamma-ray isotopic ratio measurements for 93\% plutonium-239 samples. For bulk samples the isotopic ratios necessary for calorimetric assay can be determined in a 4-hr counting period to the following accuracies: $238 \mathrm{Pu} /{ }^{239} \mathrm{Pu} \pm 15 \% ;{ }^{3}{ }^{30} \mathrm{Pu} /{ }^{239} \mathrm{Pu}$ $\pm 15 \% ;{ }^{241} \mathrm{Pu} /{ }^{239} \mathrm{Pu} \pm 3 \% ;$ and $241 \mathrm{Am} /{ }^{239} \mathrm{Pu}$ $\pm 7 \%$. When these ratios are combined the resulting uncertainty in the ratio of plutonium-239 to total plutonium is 18. The isotopic ratio uncertainties result in an uncertainty of 38 in converting a l-W sample to grams of plutonium. (The calorimeter's thermal power error has been assumed to be $0.15 \%$.) Table 7 shows the results from the computer program CALDAT which uses the formulae of ANSI standard $15.22^{21}$ to determine the weight of plutonium in grams and its uncertainty. 


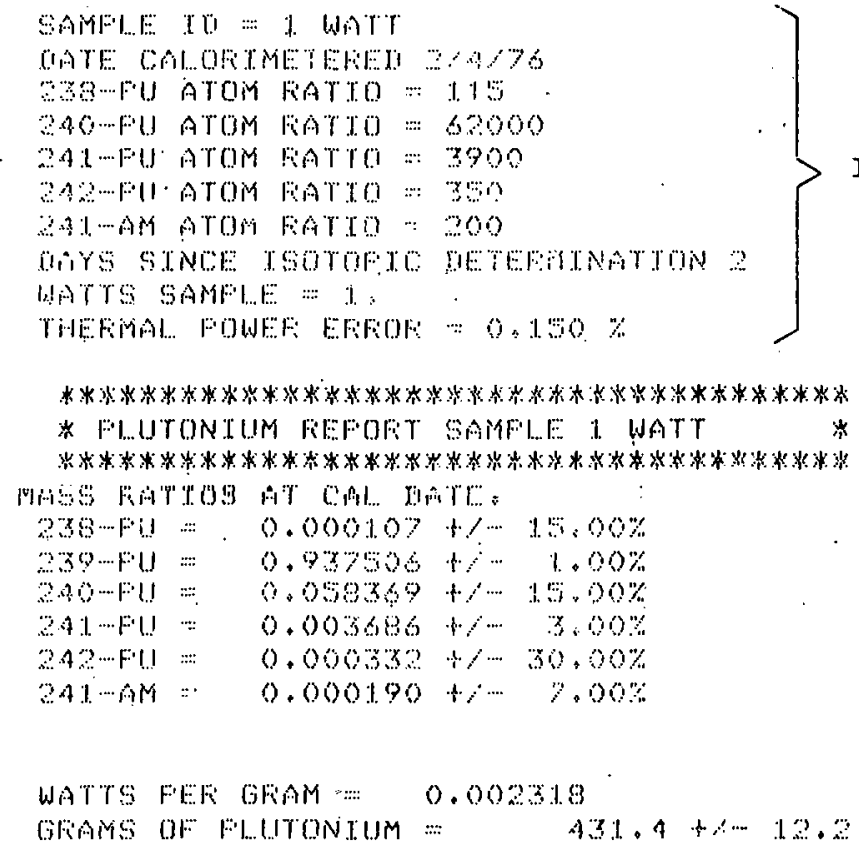

Presently, since the gamma-ray isotopic ratio measurements are not yet accurate enough to meet the goals of the Plutonium Inventory Verification Program (i.e., an overall uncertainty of less than 18 for calorimetric assay), radiocounting and mass spectrometry are used for the ${ }^{2}{ }^{38} \mathrm{Pu} / 239 \mathrm{Pu}$ and the $240 \mathrm{Pu} / 2{ }^{39} \mathrm{Pu}$ ratios.

In order to obtain a totally nondestructive assay with a lo uncertainty it will be ncceccary to obtain al! nf the

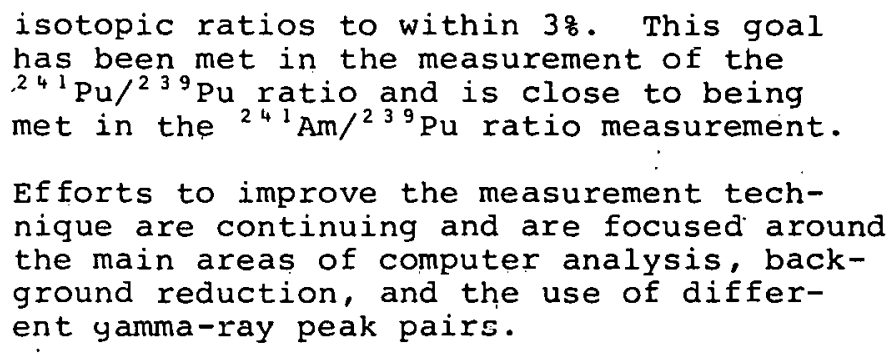
has been met in the measurement of the $.2{ }^{41} \mathrm{Pu} / 2{ }^{39} \mathrm{Pu}$ ratio and is close to being met in the ${ }^{241} \mathrm{Am} /{ }^{239} \mathrm{Pu}$ ratio measurement.

Efforts to improve the measurement technique are continuing and are focused around the main areas of computer analysis, background reduction, and the use of different yamma-ray peak pairs. 
1. R. B. Crouch, Jr., "Calorimetric Verification of Plutonium Inventories for Safeguards Surveys," in proceedings of the symposium on the Calorimetric Assay of Plutonium, October 24-25, 1973, MLM-2177 (Oct. 4, 1974), p. 96.

2. R. S. George and R. B. Crouch, Jr., Journal of the Institute of Nuclear Materials Management, IV:III, 327 (February 1975).

3. W. W. Strohm and W. W. Rodenburg, Journal of the Institute of Nuclear Materials Management, II:II, 415 (1973).

4. F. A. O'Hara, W. W. Strohm and F. X. Haas, Transactions of the American Nuclear Society, 15, 682 (November 1972).

5. For details concerning calorimetric assay, consult proceedings of the symposium , on the Calorimetric Assay of Plutonium, October 24-25, 1973, MLM-2177 (Oct. 4, 1974). See also F. A. O'Hara, J. D. Nutter, W. W. Rodenburg and M. L. Dinsmore, Calorimetry for Safeguards Purposes, MLM-1798 (Jan. 5, 1972).

6. H. W. Kraner, on the Use of Gamma-Ray Spectroscopy to Determine Pu Isotopic Abundances in Plutonium Sources, BNL-50237 (T-573) (1970).

7. F. X. Haas and J. Y. Jarvis, "Determination of Plutonium Isotopic Ratios Using Gamma-Ray Spectroscopy," in Mound Laboratory Isotopic Power Fuels Programs: AprilJune 1973. MLM-2080 (Sept. 7, 1973), pp. 34-40.

8. F. X. Haas, "Nondestructive Measurement of Plutonium Isotopic and Americium Concentrations Using Gamma-Ray Spectroscopy," in proceedings of the Symposium on the Calorimetric Assay of Plutonium, October 24-25, 1973, MLM-2177 (0ct. 4, 1974), pp. 60-65.

9. F. X. Haas, "Plutonium Isotopic Measurements by Gamma-Ray Spectroscopy," in Mound Laboratory Activities for the Division of Safeguards and Security: January-June 1974, MLM-2186 (Dec. 27, 1974), pp. 6-12.

10. F. X. Haas and $W$. W. Strohm, in IEEE Transactions on Nuclear Science, NS-22, 734-738 (February 1975).

11. R. Gunnink, "plutonium Isotopic Measurements by Gamma-Ray spectrometry," in Proceedings of the Symposium on the Calorimetric Assay of Plutonium, October 24-25, 1.973, MLM-2177 (Oct. 4, 1974), pp. 45-59.

12. R. Gunnink, J. B. Niday and P. D. Siemens, A System for Plutonium Analysis by GammaRay Spectrometry, UCRL-51577, Pt. I (1974).

13. R. Gunnink and I, F. Tinney, Analysis of Fuel Rods by Gamma-Ray Spectroscopy, UCRL-51086, University of California Radiation Laboratory, Livermore, Calif.

(Aug. 3, 1971).

14. T. D. Reilly and J. L. Parker, A Guide to Gamma-Ray Assay for Nuclear Material Accountability, LA-5794-MS (1975).

15. H. Ottmar and C. Weitkamp, "Comments on Isotopic Analysis by Gamma Spectrometry," in Symposium of Practical Application of Research and Development in the Field of Safeguards, Rome (March 7-8, 1974).

16. R. Gunnink and R. J. Morrow, Gamma-Ray Energies and Absolute Branching Intensities for $238,239,240,241 \mathrm{Pu}$ and ${ }^{2}{ }^{1} \mathrm{Am}$, UCRL-51087, University of California Radiation Laboratory, Livermore, Calif. (July 22, 1971), 26 pp.

17. "Specifications for Ge(Li) Spectroscopy Systems for Material Protection Measurements. Part 1: Data Acquisition System," Regulatory Guide 5.9, U. S. Nuclear Regulatory Commission, Washington, D. C. (June 1963), 8 pp. 
18. R. G. Helmer and M. H. Putnam, GAUSS V, A Computer Program for the Analysis of Gamma-Ray Spectra from Ge(Li) spectrometers, ANCR-1043, Aerojet Nuclear Corp., Idaho Falls, Ida. (January 1972), 68 pp.

19. R. Gunnink, A Simulation Study of Plutonium Gamma-Ray Groupings for Isotopic Ratio Determinations, UCRL-51605, University of California Radiation Laboratory, Livermore, Calif. (June 10, 1974), 58 pp.

20. T. Dragnev and $K$. Scharf, International Journal of Applied Radiation and Isotopes, $26,125(1975)$.

21. "American National Standard Calibration Techniques for the Calorimetric Assay of Plutonium-Bearing Solids Applied to Nuclear Materials Control," ANSI-N15.22-1975, American National Standards Institute, Inc., New York, N. Y., June 5, 1975. 


\section{EXTERNAL}

TID-4500, UC-15

F. J. Arsenault, NRC

C. D. Bingham, NBL

J. A. Chacon, ERDA/DAO

R. N. Chanda, Rocky Flats

L. L. Cleland, LLL

R. B. Crouch, Jr., ERDA/ALO

R. 'K.' Flitcraft, MRC

W. J. Gallagher, ERDA/SFO

R. Gunnink, LLL

G. A. Hammond, ERDA/DSS

W. A. Higinbotham, BNL/TSO

R. B. Jones, NRC

S. Kops, ERDA/CO

E. May, NRC

S. C. T. MCDowell, ERDA/DSS

R. Perry, ANL

H. E. Ransom, ERDA/RO

J. Selleck, NRC

T. E. Shea, NRC

D. M. Sikes, ERDA/DSS

A. J. Skinner, ERDA/SRO

P. Ting, NRC

R. B. Walton, LASL

E. V. Weinstock, BNL/TSO

W. H. Zimmer, ARHCO

Technical Report Library, Monsanto, St. Louis Howard Mattson, Monsanto, St. Louis

IN'TERNAL
J. H. Birden
H. S. Carden
W. T. Cave
M. F. Duff.
C. L. Fellers
F. X. Haas
C. W. Huntington
J. Y. Jarvis
J. F. Lemming
J. R. McClain
R. A. Neff

W. W. Rodenburg

P. W. Seabaugh

D. E. Sellers

W. E. Sheehan

W. H. Smith

W. W. Strohm

R. E' Vallee

H. A. Woltermann Records Center

Library (15)

Publications 